B I O S C I E N C E

J O U R N A L

\title{
BIOETHANOL PRODUCTION FROM URBAN CELLULOSIC \\ WASTE EMPLOYING Alcaligenes faecalis HI-1 ISOLATED FROM GUT OF TERMITE Heterotermes indicola
}

\author{
Mehwish IQTEDAR ${ }^{1}$ (D) , Sidra RIAZ ${ }^{1}$ (D), Saima Shehzad MIRZA ${ }^{2}$ (D) Mahwish AFTAB $^{1}$ (D), \\ Afshan KALEEM ${ }^{1}$ (iD), Roheena ABDULLAH ${ }^{1}$ (D) Ayesha AEIHTESHAM ${ }^{3}$ (i), \\ Farheen ASLAM $^{3}$ (iD, Myra WASIM ${ }^{3}$ iD
}

1 Department of Biotechnology, Lahore College for Women University, Lahore, Pakistan.
2 Microbiology Laboratory, Punjab Bioenergy Institute, University of Agriculture, Faisalabad, Pakistan.
${ }^{3}$ Department of Zoology, Quid e Azam campus, University of the Punjab, Lahore.

Corresponding author:

Mehwish lqtedar

Email: miqtedar@gmail.com

How to cite: IQTEDAR, M., et al. Bioethanol production from urban cellulosic waste employing Alcaligenes faecalis $\mathrm{HI}-1$ isolated from gut of termite Heterotermes indicola. Bioscience Journal. 2021, 37, e37023. https://doi.org/10.14393/BJ-v37n0a2021-53598

\begin{abstract}
This study assessed the potential of termite gut inhabiting bacteria towards bioconversion of cellulosic waste into biofuel. Total seven bacterial isolates from the gut of Heterotermes indicola were isolated. Among all the isolates, $\mathrm{HI}-1$ produced the largest zone upon primary screening. Untreated paper had more cellulose content (73.03\%) than acid (0.5\%) treated paper that was used as a lignocellulosic substrate for saccharification. Among all the isolates tested, glucose yield $(1.08 \mathrm{mg} / \mathrm{mL})$ was high for HI- 1 isolate. Several factors were considered for optimizing augmented glucose yield $(8.57 \mathrm{mg} / \mathrm{mL})$ and growth $\left(8.07 \times 10^{8} \mathrm{cfu} / \mathrm{mL}\right)$, such as temperature $37^{\circ} \mathrm{C}, \mathrm{pH} 4.5,5 \%(\mathrm{w} / \mathrm{v})$ substrate concentration, $6 \%$ bacterial inoculum size, agitation $150 \mathrm{rpm}$ with PEG $0.25 \%$ and $\mathrm{Ca}^{2+}$ ions $0.002 \mathrm{~g} / \mathrm{L}$. Overall 8-fold increase in glucose yield was achieved. Enzyme activity of $\mathrm{HI}-1$ showed higher endoglucanase $0.29 \pm 0.01(\mathrm{U} / \mathrm{mL} / \mathrm{min})$ and exoglucanase $0.15 \pm 0.01$ $(\mathrm{U} / \mathrm{mL} / \mathrm{min})$ activity under optimum conditions, mentioned above. temperature $37^{\circ} \mathrm{C}, \mathrm{pH} 4.5$, substrate concentration $5 \%$, inoculum size $6 \%$, surfactants PEG $0.01 \%$, ions $\mathrm{Ca}^{2+}(0.002 \mathrm{~g} / \mathrm{L})$ and agitation $(120 \mathrm{rpm})$. Simultaneous saccharification and fermentation (SSF) of hydrolyzed office paper yielded $5.43 \mathrm{mg} / \mathrm{mL}$ bioethanol. According to $16 \mathrm{~S}$ rRNA sequence homology, the bacterial isolate $\mathrm{H} 1$ was identified as Alcaligenes faecalis. Bioethanol production from office paper untreated waste proved an effective strategy. Bacteria having natural tendency towards cellulosic waste consumption are promising for bioconversion of cellulosic waste to valuable products.
\end{abstract}

Keywords: Bioethanol. Cellulolytic Bacteria. Office Paper. Termite Gut.

\section{Introduction}

Fossil fuel depletion causes increase in oil prices and petroleum products that led to a sharp interest in finding alternative energy sources. Biofuels can substitute fossil fuels and confer several advantages, ie., produced from renewable sources, lessens greenhouse gas emissions, and cost effective (Wyman 1994). In previous years, cellulases from cellulolytic bacteria have been applied in biofuel production due to their unique saccharolytic properties (Chang and Yao 2011). Cellulose, being an abundant biopolymer on earth, is the best resource for renewable energy (Rezaei et al. 2008). Bioethanol generated from cellulose in the form of agro-industrial waste has an improved eco-balance, as it does not compete with the food production, while on the other hand, it is readily accessible at low cost (Zhou et al. 2007). Paper materials are the largest 
municipal solid waste product (Muttamara et al. 1994). Therefore, it is necessary to find ways for the conversion of wastepaper and its products into consumable value (Van Wyk 2003). Cellulose is the main synthesizing unit of paper which can enzymatically be transformed into sugar molecules that can later be fermented into ethanol.

The guts of some insects like termites, beetles, leaf cutting ants and wood feeding roaches are highly adapted to diverse microflora and are considered highly competent natural bioreactors. Microtermes obesi, Microtermes mycophagous, Odontotermes obesus, Eremotermes paradoxalis and Microtermes unicolor are the most documented termite species from ecosystems of Pakistan (Ahmed et al. 2004). The microflora of the termite gut has a considerable impact on the degradation of cellulose from complex biopolymers like wood and other materials containing cellulose and hemicelluloses (Varma et al. 1994). Several facultative anaerobes have been isolated from the gut of different species of termites including Clostridium nzayombii and Homoacetogens termitida (Kane et al. 1991). Cellulolytic species of bacteria from certain phyla such as Thermotogea, Spirochaetes, Proteobacteria, Firmicutes, Actinobacteria, Bacteroids and Fibrobacteres have been reported from termite gut (Bergquist et al. 1999).

To digest cellulose, cellulolytic microorganisms produce cellulases, an extracellular complex of multienzymes or as single polypeptides having multiple cellulosic domains. Cellulases have gained much attention because of their diversity and practical applications in pharmaceutical, fiber, textile industries, laundry detergents and in fermentation of biomass for biofuel production. To overcome the global energy crisis, the present study aimed to develop a new approach to investigate the potential of cellulolytic bacteria isolated from termite gut and employed to eco-friendly conversion of highly cellulosic urban waste (office paper) into reducible sugars that can later be fermented into bioethanol.

\section{Material and Methods}

\section{Isolation of cellulolytic bacteria from termite gut}

Termites collected from different localities of Lahore were identified and their guts were removed according to Akhtar (1974). For isolation of cellulolytic bacteria, Carboxymethyl cellulose (CMC) media having $7 \mathrm{pH}$ was used (Kasan et al. 2008).

\section{Primary screening of cellulase producing bacteria}

Congo red assay was performed to determine the cellulolytic activity of the isolates (Upadhaya et al. 2012). Streaked plates of $\mathrm{CMC}$ media were incubated at $37^{\circ} \mathrm{C}$ for 48 hours. Colonies were flooded with Congo red stain (0.1\%) for up to $20 \mathrm{~min}$, later the stain was removed by flushing the plates with $1 \mathrm{M} \mathrm{NaCl}$. Diameters of clear zones around the colonies were measured.

\section{Pretreatment and proximate analysis of substrate}

Waste office paper was used as a cellulosic substrate, they were shred into small pieces (5 to $10 \mathrm{~mm}$ ) and were exposed to different pretreatments to analyze the \% cellulose, moisture, dust, and lignin content as reported previously (Wayman et al. 1992). Pre-treatment was done by two methods, where in one method paper was exposed to steam in the presence of dilute sulphuric acid (0.5\%) to remove lignin and hemicelluloses while the other was only steam treatment (Anwar et al. 2012).

\section{Secondary screening}

S-I media comprising (g/L) Peptone 5.0, Yeast extract 5.0, $\left(\mathrm{NH}_{4}\right)_{2} \mathrm{SO}_{4} 1.0, \mathrm{KH}_{2} \mathrm{PO}_{4}$ 1.0, $\mathrm{MgSO}_{4} .7 \mathrm{H}_{2} \mathrm{O}$ $0.3, \mathrm{KCl} 0.5$ and $1 \%$ substrate (office paper) having $\mathrm{pH}$ 7. The media was inoculated with $1 \mathrm{~mL}\left(10^{8}\right)$ of bacterial culture and incubated at $37^{\circ} \mathrm{C}$ for 5 days. Cell biomass was measured by spectrophotometric method at $600 \mathrm{~nm}$, while reducing sugar was measured according to Miller (1959). 


\section{Optimization}

Isolate having high cellulolytic activity was subjected to one factor optimization at different conditions such as temperature $37^{\circ} \mathrm{C}, 40^{\circ} \mathrm{C}$ and $55^{\circ} \mathrm{C}, \mathrm{pH} 4.5,7.0$ and 8.5 , substrate concentration 1,5 and $10 \%$, inoculums size 2,6 and $10 \%$, and agitation 150 rpm for 72 hours. Effects of surfactants such as SDS $(0.25$ $\%)$, EDTA $(0.25 \%)$, Triton X-100 (0.25\%) and PEG $(0.25 \%)$ on bacterial growth and reducing sugar yield were observed. Effects of metal ions such as $\mathrm{FeSO}_{4} .7 \mathrm{H}_{2} \mathrm{O}(0.004 \mathrm{~g} / \mathrm{L}), \mathrm{ZnSO}_{4} .7 \mathrm{H}_{2} \mathrm{O}(0.003 \mathrm{~g} / \mathrm{L})$ and $\mathrm{CaCl}_{2} .2 \mathrm{H}_{2} \mathrm{O}$ $(0.002 \mathrm{~g} / \mathrm{L})$ were also studied on bacterial growth and cellulolytic activity. Media used for optimization was S-I.

\section{Enzyme activity: CMCase assay}

For CMCase assay $100 \mu \mathrm{L}$ of crude enzyme was mixed with $900 \mu \mathrm{L}$ of $1 \% \mathrm{CMC}(1 \mathrm{~g}$ of CMC dissolved in $20 \mathrm{mM}$ of phosphate buffer having $\mathrm{pH} 7.0$ ) kept at $50^{\circ} \mathrm{C}$ for 30 minutes. After incubation, the reaction was stopped by adding $1 \mathrm{~mL} 3$, 5-Dinitrosalicylic acid solution and kept in boiling water for 5 minutes and then cooled at room temperature. Reducing sugar was measured as reported previously (Miller 1959). Endo- $\beta-1$, 4-glucanase activity was defined in one unit as; "amount of enzyme that can hydrolyze CMC and liberate $1 \mu \mathrm{L}$ glucose per minute at $50^{\circ} \mathrm{C}^{\prime \prime}$.

$\mathrm{CMCase}$ activity $(\mathrm{IU} / \mathrm{mL} / \mathrm{min})=$ Absorbance $\times$ Standard Factor/ Incubation time.

\section{Enzyme activity: FPase assay}

For FPase assay, $1 \mathrm{~mL}$ of culture aliquot was centrifuged at $10,000 \mathrm{rpm}$ for 10 minutes and then mixed with $50 \mathrm{mg}$ strip of Whatman filter paper $(1 \times 6 \mathrm{~cm})$, immersed in $1 \mathrm{~mL}$ of $0.05 \mathrm{M}$ sodium phosphate buffer at pH 5.0 and incubated at $50^{\circ} \mathrm{C}$ for 60 minutes (Mandels et al., 1976). After incubation, $1 \mathrm{~mL}$ of DNS solution was added and boiled for about 5 minutes and later cooled to room temperature. The reducing sugar was measured by DNS method (Miller 1959). The activity of exoglucanase in one unit was described as "enzyme amount that can release $1 \mu$ mole reducing sugar in one min from filter paper".

FPase activity $(\mathrm{IU} / \mathrm{mL} / \mathrm{min})=$ Absorbance $\times$ Standard Factor/ Incubation time .

\section{Simultaneous saccharification and fermentation (SSF)}

The yeast (Saccharomyces cerevisae) inoculum of 24 hours $\left(10^{6}\right)$ was prepared in YPD media containing $1 \%$ yeast extract, $2 \%$ peptone and $5 \%$ glucose (Anwar et al. 2012). Simultaneous saccharification and fermentation was carried out in $250 \mathrm{~mL}$ flasks that contained $100 \mathrm{~mL} \mathrm{S-I} \mathrm{medium.} \mathrm{Media} \mathrm{was} \mathrm{aseptically}$ inoculated with $5 \%$ yeast suspension (Saccharomyces cerevisae). Anaerobic conditions were established by fitting a rubber cork over each flask and one end of capillary was inserted into it whereas the outer tip was dipped in $\mathrm{Ca}(\mathrm{OH})_{2}$. SSF experiments were performed under optimum conditions temperature $37^{\circ} \mathrm{C}, \mathrm{pH} 4.5$, substrate concentration $5 \%$, inoculum size $6 \%$, surfactants PEG $0.01 \%$, ions $\mathrm{Ca}^{2+}(0.002 \mathrm{~g} / \mathrm{L})$ and agitation $(120$ rpm) for a period of 3 days. The ethanol produced during SSF was estimated by HPLC.

\section{Ethanol estimation by HPLC}

The aliquots of fermented products were analyzed by HPLC (Shimadzu Corporation Koyoto, Japan) for estimation of ethanol yield. The samples were quantified by using the column CLC-NH . The mobile phase used was acetonitrile and water $(75: 25, \mathrm{v} / \mathrm{v})$ at $1 \mathrm{~mL} / \mathrm{min}$. The injection volume was $10 \mu \mathrm{L}$ and column temperature was maintained at room temperature.

\section{Molecular identification}

Based on 16S rDNA sequence, identification of bacterial isolate $\mathrm{H}-\mathrm{SC} 1$ was done through First Base Company (Singapore) using sequencing primers 785F 5' (GGA TTA GAT ACC CTG CTA) 3' and 907R 5' (CCG TCA ATT CMT TTR AGT TT) 3'. PCR primers used were 27F 5' (AGA GTT TGA TCM TGG CTC AG) 3' and 1492R 5' (TAC GGY TAC CTT GTT ACG ACT T) 3'. The phylogenetic relationship was checked based on homology sequence by Neighbor joining method (Saitou and Nei 1987; Sambrook and Russell 2001). 


\section{Statistical analysis}

All experiments were performed in triplicates. Data was analyzed using software SPSS 16.0. Duncan's Multiple Range test was performed on the data to calculate significance difference $(p \leq 0.05)$ between values obtained at different conditions. Intergroup differences in proximate analysis and secondary screening were calculated by applying t-test with significance at $p \leq 0.05$.

\section{Results and Discussion}

The present study was undertaken to investigate the potential of cellulolytic bacteria isolated from the gut of termites in bioconversion of highly cellulosic urban waste, and office paper into reducible sugars that was later fermented to bioethanol. Termite specie collected for this study was identified as Heterotermes indicola. Seven bacterial strains were isolated from $\mathrm{H}$. indicola. Alcaligenes faecalis $\mathrm{HI}-1$ from the current study was identified as facultative anaerobe. Other facultative anaerobes Bacillus cereus (Thayer 1976; Ramin et al. 2009), Cellulomonas (Wenzel et al. 2002), Cellulomonas pachnodae (Bakalidou et al. 2002), Enterobacter aerogenes and Acinetobacter (Ramin et al. 2009) had been reported from guts of termites and were capable of lignocellulosic degradation. Alcaligenes has been reported from hind-gut of other termite specie such as Reticulitermes hesperus (Thayer 1976) and Odontotermes obesus (Devi et al. 2006) and identified as facultative wood digesting bacteria, however it is not previously reported from Heterotermes indicola.

\section{Primary screening}

In the primary screening all bacterial isolates produced clear zones against Congo red reagent which confirmed their cellulolytic nature (Figure $1 \mathrm{~A}$ ).

\section{Proximate analysis}

In the present study an important urban cellulosic waste, an office paper, has been considered a cheap substrate for bioethanol production (Coman et al. 2012). Utilization of office paper waste is beneficial in two ways as, on one side waste is managed and on the other side a useful product i.e., biofuel is produced. Different studies have been conducted on the bioconversion of wastepaper to bioethanol. Proximate analysis of pretreated and control samples revealed that cellulose and lignin content of untreated office paper were $73 \%$ higher as compared to pretreated office paper (67\%). Whereas moisture and ash content were significantly $(p \leq 0.05)$ higher in pretreated office paper (Table 1$)$. There might be a possibility that sulfuric acid not only dissolved lignin but also affected cellulose content thereby producing undesirable products. In this context, it can be concluded that in case of wastepaper, pretreatment is not necessary for efficient bioconversion to bioethanol (Zhu et al. 2011).

Table 1. Proximate analysis of untreated and pretreated $\left(0.5 \% \mathrm{H}_{2} \mathrm{SO}_{4}\right)$ office paper.

\begin{tabular}{ccccc}
\hline Substrate condition & \% Moisture & \% Ash & \% Cellulose & \% Lignin \\
\hline Untreated & $5.18 \pm 0.02$ & $2.33 \pm 0.01$ & $73.03 \pm 0.04 *$ & $18.02 \pm 0.03^{*}$ \\
Pretreated & $7.0 \pm 0.02 *$ & $2.52 \pm 0.02 *$ & $67.04 \pm 0.05$ & $13 \pm 0.05$ \\
\hline
\end{tabular}

Data has been analyzed by applying t-test with significance at $p \leq 0.05$ represented by *.

\section{Secondary screening}

All the isolates produced significantly higher $(p \leq 0.05)$ glucose by utilizing untreated office paper as compared to pretreated office paper (Figure $1 \mathrm{~A}$ ). The highest glucose producing bacterial isolate was Alcaligenes faecalis $\mathrm{HI}-1$ that produced $1.07 \pm 0.04(\mathrm{mg} / \mathrm{mL})$ of glucose with significantly $(p \leq 0.05)$ higher cell biomass up to $2.60 \times 10^{8} \pm 0.004$ (cells $/ \mathrm{mL}$ ) (Figure 1B). Previous studies focused only on the enzymatic conversion of wastepaper to sugar monomers (Van Wyk 2003). Whereas in the current study cellulolytic bacteria from the termite gut was used to convert cellulose waste to generate glucose monomers. 
A

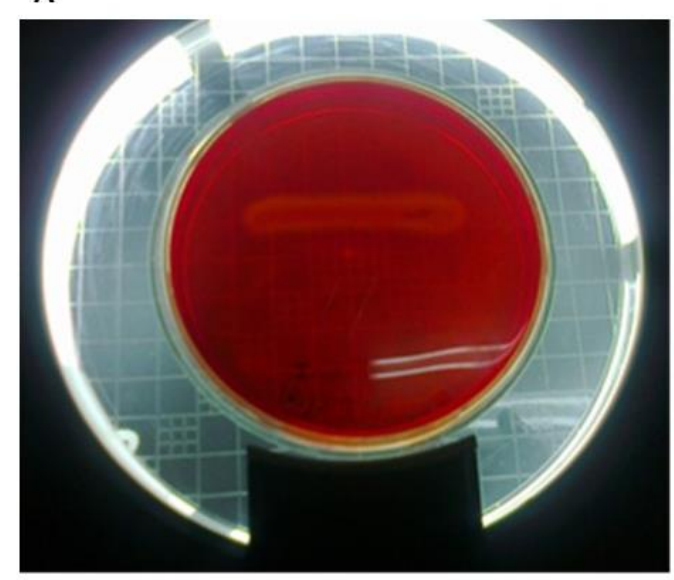

B

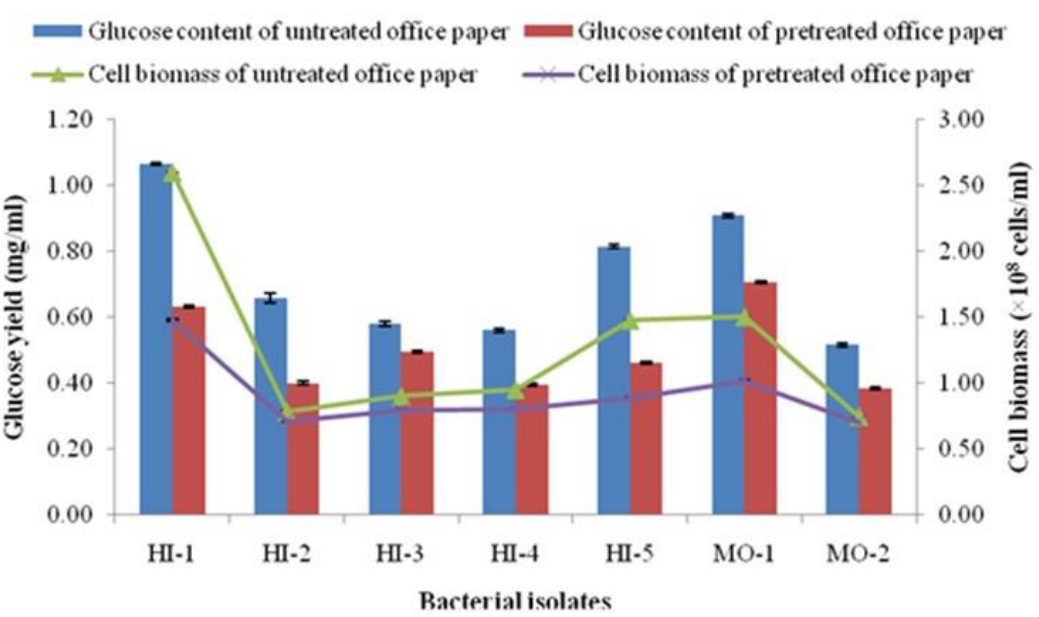

Figure 1. A - halozones formed by cellulolytic bacteria HI-1 in Congo red media; B - growth ( $10^{8}$ cells $/ \mathrm{mL}$ ) and glucose yield $(\mathrm{mg} / \mathrm{mL}$ ) by cellulolytic bacterial isolates obtained from termite gut during secondary screening using office paper at different conditions.

\section{Optimization}

Enhanced cellulase activity relies heavily on various physicochemical factors and the current study focused on standardizing the physical and biochemical conditions for maximum enzyme activity and enhanced glucose concentration.

\section{Temperature}

Incubation temperature has considerable effect on the growth, survival and metabolism of microorganisms and their activities. Glucose release and bacterial growth were the two parameters studied during optimization using untreated office paper (Figure $2 \mathrm{~A}$ ). It was found that Alcaligenes faecalis $\mathrm{HI}-1 \mathrm{had}$ significantly $(p \leq 0.05)$ higher growth $\left(3.33 \times 10^{8} \pm 0.02\right.$ cells $\left./ \mathrm{mL}\right)$ with enhanced glucose yield $(2.36 \pm 0.02$ $\mathrm{mg} / \mathrm{mL}$ ) at temperature $37{ }^{\circ} \mathrm{C}$ after 48 hours of incubation. As Alcaligenes faecalis $\mathrm{HI}-1$ showed both increased cellulase activity and cell biomass with respect to glucose production at $37 \circ \mathrm{C}$, indicating that bacteria had efficiently utilized the substrate (office paper) by producing enzymes that efficiently converted the cellulose of substrate into glucose. Bacillus subtilis, Pseudomonas fluorescence, Bacillus sp., Cellulomonas and Micrococcus sp. have been reported to exhibit maximum growth and cellulase activity at temperature range from $37-40^{\circ} \mathrm{C}$ (Immanuel et al. 2006).

\section{pH}

In the current study Alcaligenes faecalis $\mathrm{HI}-1$ showed highest cell biomass and maximum glucose yield $(\mathrm{mg} / \mathrm{mL})$ at $\mathrm{pH} 4.5$ with a fold increase in glucose yield. Increase in bacterial biomass was $3.86 \times 10^{8} \pm 0.02$ (cells $/ \mathrm{mL}$ ) and glucose yield was $3.43 \pm 0.01(\mathrm{mg} / \mathrm{mL}$ ) after 48 hours of incubation (Figure $2 \mathrm{~B}$ ). $\mathrm{pH}$ had a profound effect on microorganisms and their activities. The change in the $\mathrm{pH}$ might have affected ionic bonding of the enzymes that may affect functional structure of the enzymes which degrade cellulose (Mussatto et al. 2008). Maximum activity of cellulolytic enzymes was reported between pH 4.2 to 5.8, whereas $\mathrm{pH} 4.8$ has been considered optimal for the stability of cellulase enzymes (Pardo and Forchiassin 1999).

\section{Substrate concentration}

Optimum concentration of substrate for Alcaligenes faecalis $\mathrm{HI}-1$ was $5 \%$ that liberated glucose up to $5.02 \pm 0.03(\mathrm{mg} / \mathrm{mL}$ ) after 48 hours of incubation (Figure $2 \mathrm{C}$ ). High degree of glucose yield obtained from hydrolysis of paper materials is also reported by other authors but at low substrate concentration (Wayman et al. 1992; Solange et al. 2008). 

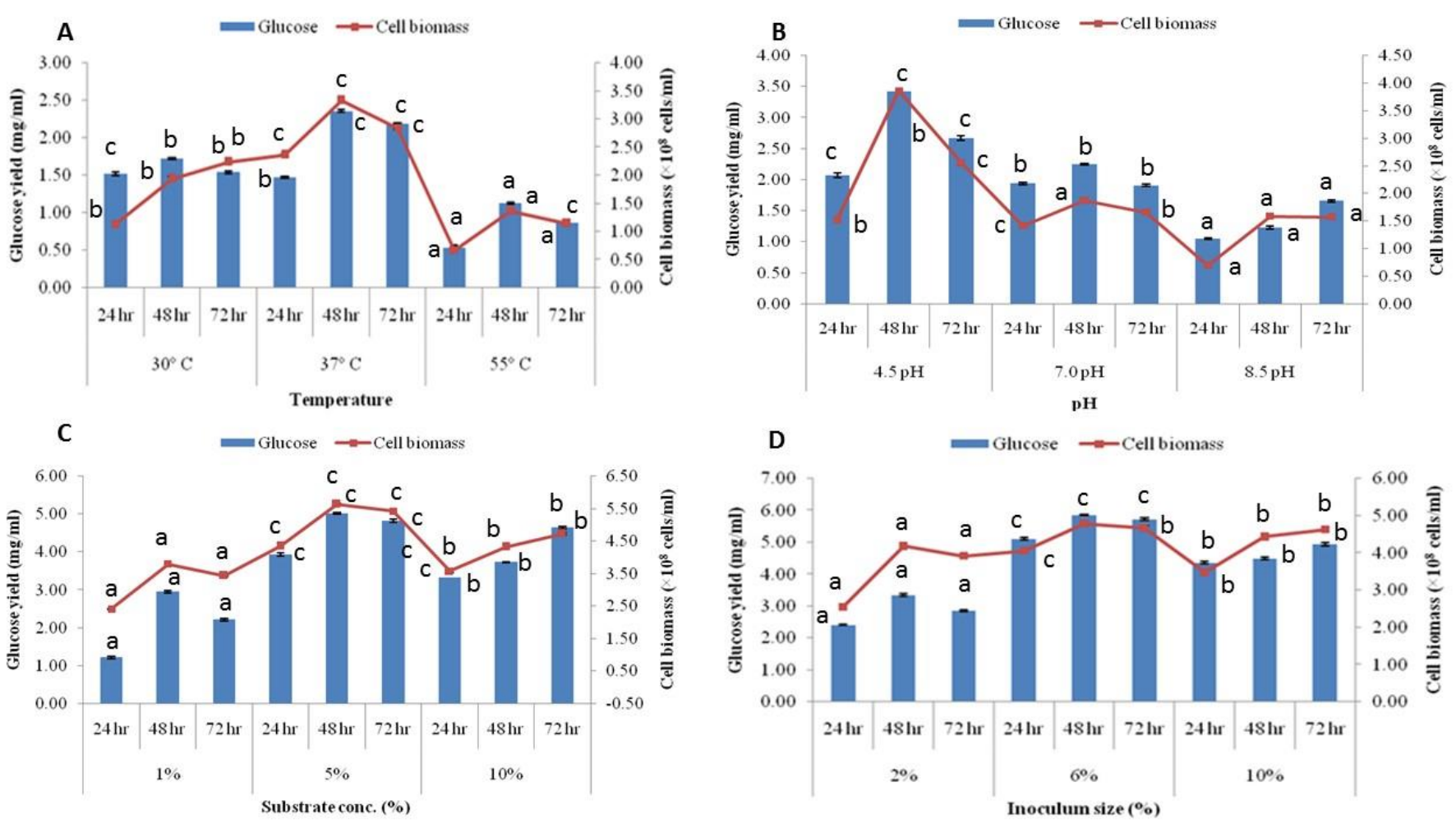

Figure 2. Cell biomass and glucose production by Alcaligenes faecalis $\mathrm{HI}-1$ under different physic-organic conditions. A - temperature; B - pH; C-substrate concentration; D - inoculum. Superscripts shows significant difference at $p \leq 0.05$.

\section{Inoculum concentration}

Glucose yield increased further to $5.86 \pm 0.03(\mathrm{mg} / \mathrm{mL})$ by increasing the inoculum concentration to $6 \%$. Alcaligenes faecalis $\mathrm{HI}-1$ showed $17 \%$ increase in glucose content with increased cell biomass at $6 \%$ inoculum in saccharification medium of office paper (Figure 2D). There is currently no work available in which Alcaligenes faecalis $\mathrm{HI}-1$ bacterial inoculum is optimized for production of glucose during saccharification. Currently, a different approach is undertaken in which cellulose degradation potential of cellulolytic bacteria isolated from the termite gut was studied by utilizing office wastepaper.

\section{Agitation}

A significant increase in glucose yield $(6.76 \pm 0.04 \mathrm{mg} / \mathrm{mL})$ was obtained with 48 hours of agitation (120rpm) (Figure 3A). Sufficient oxygen is necessary for the cells for efficient activity.

\section{Surfactants}

Among the surfactants used, a significant $(p \leq 0.05)$ decrease in cell biomass as well as glucose production was observed with SDS, EDTA and Triton X100, while PEG (0.1\%) enhanced the glucose yield to $7.88 \pm 0.06(\mathrm{mg} / \mathrm{mL}$ ) after 24 hours (Figures $3 B$ and $3 C$ ). PEG, because of its hydrophobic nature can modify the structure of substrate and therefore enhances the availability of cellulose for the enzyme activity. PEG adsorbs on the surface of lignin and repels the enzymes for unproductive binding (Sipos et al. 2010).

\section{Metal ionsm}

Addition of metal ions to the culture showed that $\mathrm{Ca}^{2+}$ ions increased the cell biomass to $8.07 \times 10^{8} \pm 0.07$ (cells $/ \mathrm{mL}$ ) along with increasing the glucose yield $(8.57 \pm 0.08 \mathrm{mg} / \mathrm{mL}$ ) to 8 -fold after 24 hours of incubation (Figure 3D). Addition of $\mathrm{Ca}^{2+}$ ions $(0.002 \mathrm{~g} / \mathrm{L})$ to the media enhances cellulase production was also inferred by Shankar and Isaiarasu (2011). 

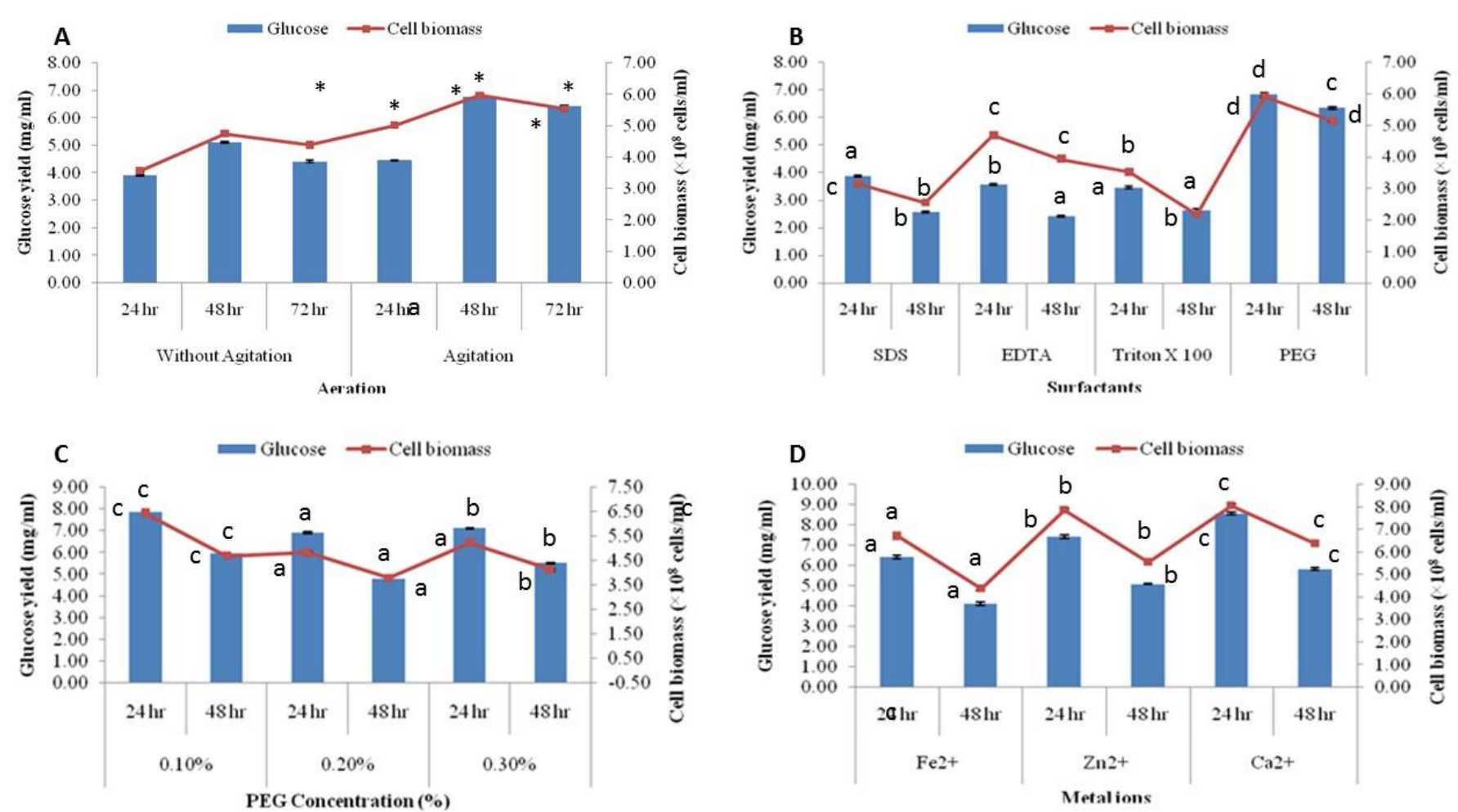

Figure 3. Cell biomass and glucose production by Alcaligenes faecalis $\mathrm{HI}-1$ under different physic-organic conditions. A - agitation (120rpm); B - surfactants SDS (0.25\%), EDTA (0.25\%), Triton X-100 (0.25\%) and PEG (0.25\%); $\mathrm{C}$ - optimizing different concentrations of PEG; $\mathrm{D}$ - metal ions $\mathrm{FeSO}_{4} .7 \mathrm{H}_{2} \mathrm{O}(0.004 \mathrm{~g} / \mathrm{L})$, $\mathrm{ZnSO}_{4} .7 \mathrm{H}_{2} \mathrm{O}(0.003 \mathrm{~g} / \mathrm{L})$ and $\mathrm{CaCl}_{2} .2 \mathrm{H}_{2} \mathrm{O}(0.002 \mathrm{~g} / \mathrm{L})$. Superscripts shows significant difference at $\mathrm{p} \leq 0.05$.

\section{Enzyme assays}

Alcaligenes faecalis $\mathrm{HI}-1$ showed higher CMCase (endoglucanase) $0.29 \pm 0.01(\mathrm{U} / \mathrm{mL} / \mathrm{min}$ ) and FPase (exoglucanase) $0.15 \pm 0.01\left(\mathrm{U} / \mathrm{mL} / \mathrm{min}\right.$ ) activity at $4.5 \mathrm{pH}$ and at $37^{\circ} \mathrm{C}$ after 72 hours of incubation in the presence of PEG $(0.1 \%)$ and calcium chloride $(0.002 \mathrm{~g} / \mathrm{L})$ (Figures $4 \mathrm{~A}$ and $4 \mathrm{~B})$. Other authors have reported increase in CMCase and FPase productivity under similar conditions with pH range of 4.2 to 5.8 (Pardo and Forchiassin 1999; Abo-State el al. 2013). Whereas pH 4.8 has been considered optimal for stability of cellulase enzymes (Pardo and Forchiassin 1999).

\section{Simultaneous saccharification and fermentation (SSF)}

Fermentation was carried out for the saccharified substrate obtained from Alcaligenes faecalis HI-1 under optimum conditions. Fermentation conditions were: $5 \%$ substrate concentration, $6 \%$ inoculums size, $\mathrm{pH} 4.5,5 \%$ inoculum of $\mathrm{S}$. cerevisae, agitation at $150 \mathrm{rpm}$ at $37^{\circ} \mathrm{C}$ for a period of 3 days. Although temperature was not optimum for the yeast, it showed the metabolic activity. The ethanol yield obtained by saccharification of office wastepaper by cellulolytic strain Alcaligenes faecalis $\mathrm{HI}-1$ was $5.43 \mathrm{mg} / \mathrm{mL}$ (Figure 5). Bioethanol reported by enzymatic saccharification of wastepaper has been reported in another study by Ballesteros et al (2002). However, in these studies direct saccharification was done by using commercial enzymes. In the present study, the application of cellulolytic bacteria for cellulase production instead of using cellulase enzymes was a novel and cost-effective approach. By further refining the process the batch culture can be upgraded to continuous culture for continuous productivity of biofuel. 
A
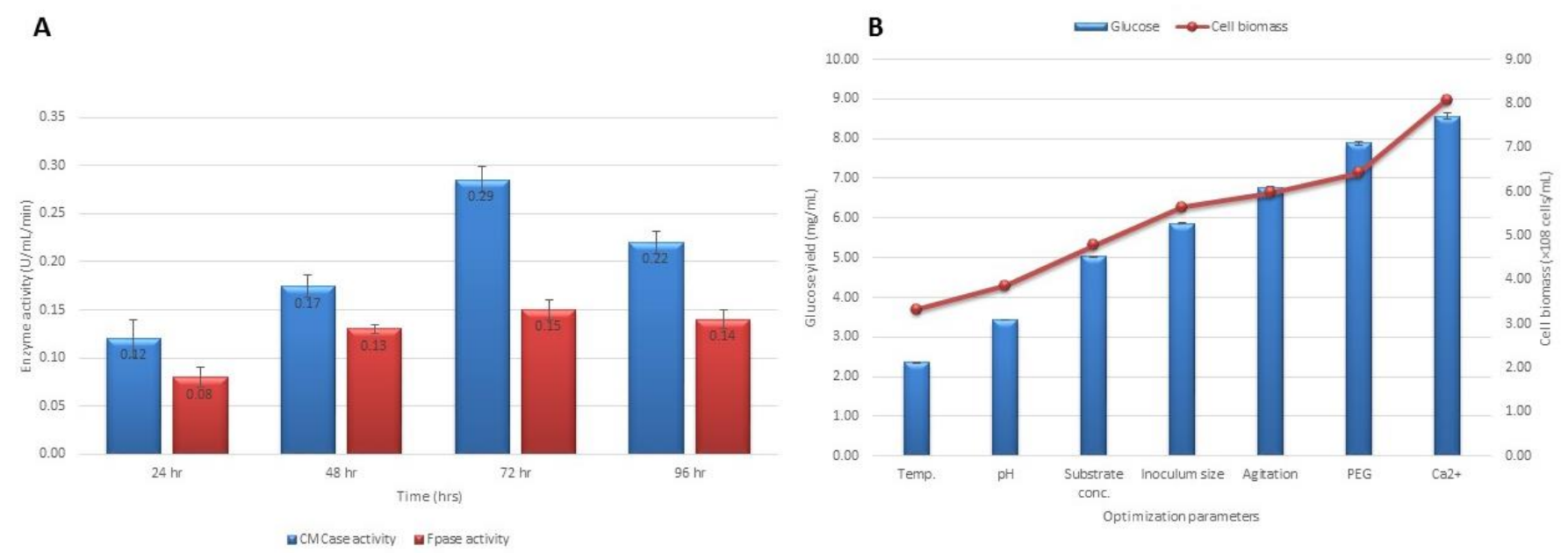

Figure 4. A - CMCase and FPase activity (U/mL/min) of Alcaligenes faecalis $\mathrm{HI}-1$ during 24 to $96 \mathrm{hrs}$ of incubation under optimum conditions temperature $37^{\circ} \mathrm{C}, \mathrm{pH} 4.5$, substrate concentration $5 \%$, inoculum size $6 \%$, surfactants PEG $0.01 \%$, ions $\mathrm{Ca}^{2+}(0.002 \mathrm{~g} / \mathrm{L})$ and agitation $(120 \mathrm{rpm}) ; \mathrm{B}$ - synergistic increase in glucose yield with growth of Alcaligenes faecalis $\mathrm{HI}-1$ under optimum conditions temperature $37^{\circ} \mathrm{C}, \mathrm{pH} 4.5$, substrate concentration $5 \%$, inoculum size $6 \%$, surfactants PEG $0.01 \%$, ions $\mathrm{Ca}^{2+}(0.002 \mathrm{~g} / \mathrm{L})$ and agitation (120 rpm).
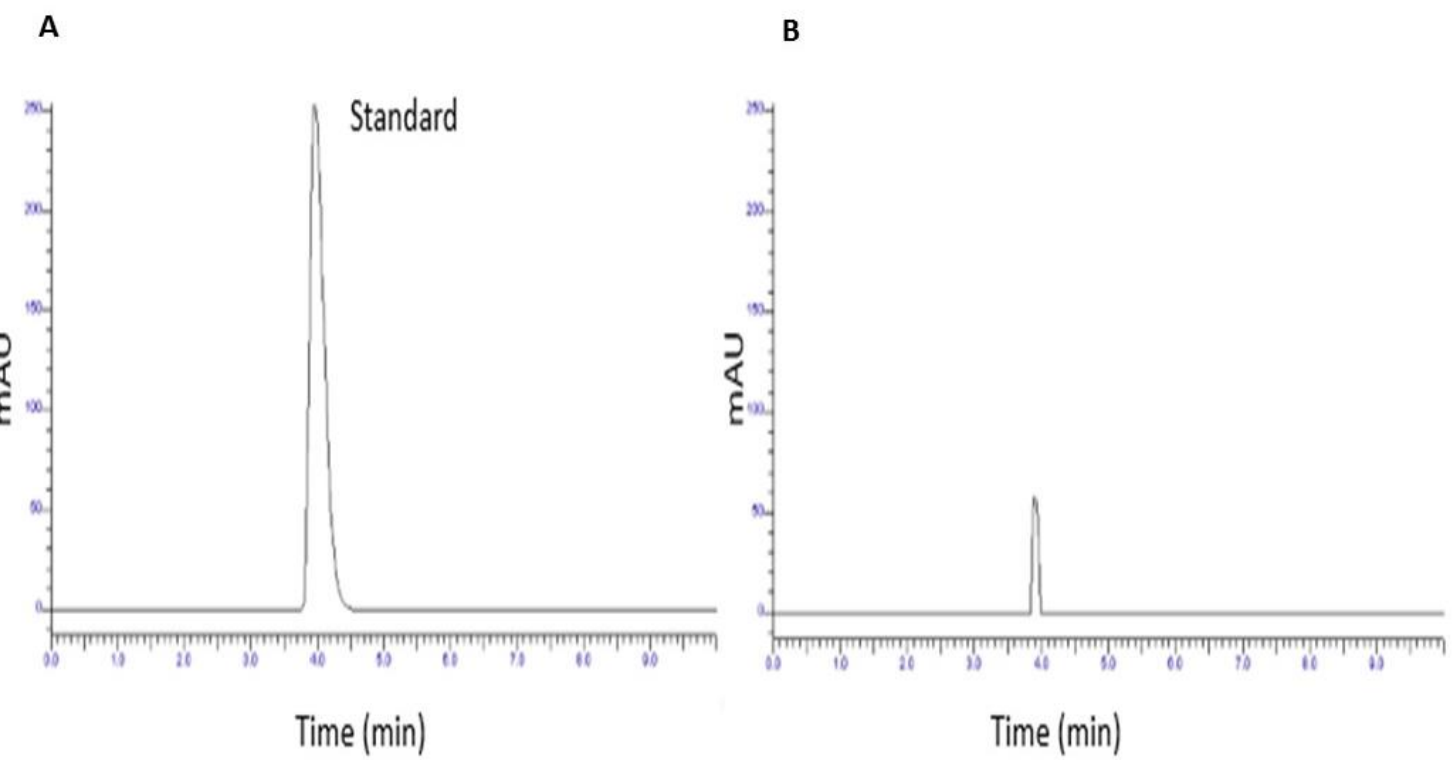

Figure 5. HPLC analysis. A - peak showing retention time of standard ethanol; B - ethanol yield after fermentation of saccharified waste office paper by Alcaligenes faecalis H1-1.

\section{S rRNA gene sequence analysis}

The amplified 16SrDNA sequence have $99 \%$ homology with specie Alcaligenes faecalis, so the isolate was designated as Alcaligenes faecalis HI-1.

\section{Conclusions}

The current study was a novel approach to produce bioethanol from office wastepaper by utilizing cellulolytic bacteria from the termite's gut. New habitats must be searched for novel cellulolytic bacteria which can ultimately lead to novel enzymes with efficient activity. The data gathered in the present study revealed that cellulolytic bacteria Alcaligenes faecalis $\mathrm{HI}-1$ isolated from gut of Heterotermes indicola was competent enough to breakdown the cellulosic content of office waste paper into glucose which can be fermented into bioethanol by Saccharomyces cerevisae. The office waste paper has the potential to be converted into bioethanol without any pretreatment and is relatively cost effective. This study provided ecofriendly bioethanol from cheap urban cellulosic waste (office paper) which can replace gasoline products 
and overcome the global energy crisis. In addition to bioethanol production, this study is also beneficial with respect to bioremediation of urban wastes where such bacteria can be employed for generating compost from urban waste.

Authors' Contributions: IQTEDAR, M.: conception and design, acquisition of data; RIAZ, S.: conception and design, acquisition of data; MIRZA, S.S.: acquisition of data; AFTAB, M.: acquisition of data; KALEEM, A.: analysis and interpretation of data; ABDULLAH, R.: analysis and interpretation of data; AEIHTESHAM, A.: acquisition of data; ASLAM, F.: drafting the article; WASIM, M.: drafting the article. All authors have read and approved the final version of the manuscript.

Conflicts of Interest: The authors declare no conflicts of interest.

Ethics Approval: Not applicable.

Acknowledgments: Authors acknowledge the cooperation and guidance provide by the entomologist Prof. Dr. Muhammad Saeed Akhtar (Zoology Department, University of the Punjab, Lahore) in collection and identification of the termites.

\section{References}

ABO-STATE, M.A.M., et al. Optimization of cellulase(s) and xylanase production by thermophilic and alkaliphilic Bacillus isolates. AmericanEurasian Journal of Agricultural \& Environmental Sciences. 2013, 13(4), 553-564. https://doi.org/10.5829/idosi.aejaes.2013.13.04.15513

AHMED, S., et al. Effect of crop rotation and intercropping on subterranean termites in wheat at Faisalabad. Pakistan Entomological. 2004, 26, 25-30.

AKHTAR, M.S. Zoogeography of the termites of Pakistan. Pakistan Journal of Zoology. 1974, 6, 85-104.

ANWAR, Z., et al. Optimization of dilute acid pretreatment using response surface methodology for bioethanol production from cellulosic biomass of rice polish. Pakistan Journal of Botany. 2012, 44, 169-176.

BAKALIDOU, A., et al. Cellulosimicrobium variabile sp. nov. a cellulolytic bacterium from the hindgut of the termite Mastotermes darwiniensis. International Journal of Systematic and Evolutionary Microbiology. 2002, 52, 1185-1192. https://doi.org/10.1099/00207713-52-4-1185

BALLESTEROS, M., et al. Ethanol production from paper material using a simultaneous saccharification and fermentation system in a fed-batch basis. World Journal of Microbiology and Biotechnology. 2002, 18, 559-561. https://doi.org/10.1023/A:1016378326762.

BERGQUIST, P.L., et al. Molecular diversity of thermophillic cellulolytic and hemicellulolytic bacteria. FEMS Microbiology Ecology. 1999, 28, 99110. https://doi.org/10.1111/j.1574-6941.1999.tb00565.x

CHANG, T. and YAO, S. Thermophilic, lignocellulolytic bacteria for ethanol production: current state and perspectives. Applied Microbiology and Biotechnology. 2011, 92(1), 13-27. https://doi.org/10.1007/s00253-011-3456-3

COMAN, G., et al. Optimization of protein production by Geotrichum candidum mug 2.15 by cultivation on paper residues, using surface response methodology. Bioresources, 2012, 7(4), 5290-5303.

DEVI, K.K., et al. Hydrogen cyanide-producing Rhizobacteria kill Subterranean Termite Odontotermes obesus (Rambur) by cyanide poisoning under in vitro conditions. Current Microbiology. 2006, 54(1), 74-78.

IMMANUEL, G., et al. Effect of different growth parameters on endoglucanase enzyme activity by bacteria isolated from coir retting effluents of estuarine environment. International Journal of Environmental Science and Technology.2006, 3(1), 25-34.

https://doi.org/10.1007/BF03325904

KANE, W.M., et al. Clostridium mayombii sp. nov., an $\mathrm{H}_{2} / \mathrm{CO}_{2}$, acetogenic bacterium from the gut of the african soil-feeding termite, Czibitermes speciosus. Archives of Microbiology. 1991,156, 99-104.

KASAN, A.R.C., et al. A rapid and easy method for the detection of microbial cellulases on agar plates using gram's iodine. Current Microbiology. 2008, 57, 503-507. https://doi.org/10.1007/s00284-008-9276-8

MILLER, G.L. Use of dinitrosalicylic acid reagent for determination of reducing sugars. Analytical Chemistry. 1959, 31, 426-442. https://doi.org/10.1021/ac60147a030

MANDELS, M., et al. Measurement of saccharifying cellulase. Biotechnology and Bioengineering Symposium. 1976, 6, 21-33. https://doi.org/10.1186/1754-6834-2-21

MUSSATTO, S.I., et al. The effect of agitation speed, enzyme loading and substrate concentration on enzymatic hydrolysis of cellulose from brewer's spent grain. Springer Science. 2008, 15, 711-721. https://doi.org/10.1007/s10570-008-9215-7

MUTTAMARA, S., et al. Solid waste recycling and reuse in Bangkok. Waste Management and Research. 1994, 12, 151-163.

https://doi.org/10.1177\%2F0734242X9401200205

PARDO, A.G. and FORCHIASSIN, F. Influence of temperature and pH on cellulase activity and stability in Nectria catalinensis. Revista Argentina de Microbiología. 1999, 31(1) 31-5. 
RAMIN, M., et al. Identification of cellulolytic bacteria isolated from the termite Coptotermes curvignathus (Holmgren). Journal of Rapid Methods and Automation in Microbiology. 2009, 17, 103-116. https://doi.org/10.1111/j.1745-4581.2009.00160.x

REZAEI, F., et al. Enzymatic hydrolysis of cellulose coupled with electricity generation in a microbial fuel cell. Biotechnology and Bioengineering. 2008, 101(6), 1163-1169. https://doi.org/10.1002/bit.22015

SAITOU, N. and NEI, M. The neighbor-joining method: a new method for constructing phylogenetic trees. Molecular Biology Evolution. 1987, 4, 406-25. https://doi.org/10.1093/oxfordjournals.molbev.a040454

SAMBROOK J. and RUSSELL, D.W. Molecular Cloning, Laboratory manual. $3^{\text {rd }}$ ed. New York: Cold spring harbour laboratory press, 2001.

SHANKAR, T. and ISAIARASU, L. Cellulase Production by Bacillus pumilus EWBCM1 under varying cultural conditions. Middle East Journal of Scientific Research. 2011, 8(1), 40-45.

SIPOS, B., et al. Hydrolysis efficiency and enzyme adsorption on steam pretreated spruce in the presence of polyethylene glycol. Enzyme and Microbial Technology. 2010, 47, 84-90. https://doi.org/10.1016/i.enzmictec.2010.05.010

SOLANGE, I., et al. The effect of agitation speed, enzyme loading and substrate concentration on enzymatic hydrolysis of cellulose from brewer's spent grain. Springer Science. 2008, 15, 711-721. https://doi.org/10.1007/s10570-008-9215-7

THAYER, D.W. Facultative wood-digesting bacteria from the hind-gut of the termite Reticulitermes hesperus. Journal of General Microbiology. 1976, 95, 287-296. https://doi.org/10.1099/00221287-95-2-287

UPADHYAYA, S.K., et al. Isolation and characterization of cellulolytic bacteria from gut of termite. Rentech Symposium Compendium. 2012, 1, 14-18.

VAN WYK, J.P.H. and MOHULATSI, M. Biodegradation of wastepaper by cellulase from Trichoderma viride. Bioresource Technology. 2003, 8, 2123. https://doi.org/10.1016/s0960-8524(02)00130-x

VARMA, A., et al. Lignocellulose degradation by microorganisms from termite hills and termite guts: a survey on the present state of art. FEMS Microbiology Reviews. 1994, 15, 9- 28. https://doi.org/10.1111/j.1574-6976.1994.tb00120.x

WAYMAN, M., et al. Bioconversion of waste paper to ethanol. Process Biochemistry. 1992, 27, 239-245. https://doi.org/10.1016/00329592(92)80024-W

WENZEL, M., et al. Aerobic and facultatively anaerobic cellulolytic bacteria from the gut of the termite Zootermopsis angusticollis. Journal of Applied Microbiology. 2002, 92, 2-40. https://doi.org/10.1046/j.1365-2672.2002.01502.x

ZHOU, X., et al. Correlation of cellulase gene expression and cellulolytic activity throughout the gut of the termite Reticulitermes flavipes. Gene. 2007, 395, 29-39. https://doi.org/10.1016/j.gene.2007.01.004

ZHU, M.; ZHU, Z. and LI, X. Bioconversion of paper sludge with low cellulosic content to ethanol by separate hydrolysis and fermentation. African Journal of Biotechnology. 2011, 10(66), 15072-15083. https://doi.org/10.5897/AJB11.1644

Received: 06 April 2020 | Accepted: 12 October 2020 | Published: 12 May 2021

This is an Open Access article distributed under the terms of the Creative Commons Attribution License, which permits unrestricted use, distribution, and reproduction in any medium, provided the original work is properly cited. 